\title{
Travelling into the World of Bilingual (Code-Switching) Concrete Poetry
}

\author{
Márta TÖRTELI TELEK \\ Jovan Jovanović Zmaj Primary School \\ Magyarkanizsa, Szerbia \\ ttmarta76@gmail.com
}

\begin{abstract}
The paper examines the complex phenomenon of intermediality, "multimedial transgression", and "culturally agitating hybridity" resonating and flashing over ages and cultures. It reviews concrete poetry, which may be considered as a real multimedial text with linguistic and pictorial coded aesthetic message, the poetic intention evolving from the mixture of verb and picture. Examining from the aesthetic of reception, code-switching of concrete poetry comes into the focus of the research. We may feel that for a recipient knowing both languages (for the recipient of concrete poetry), it is more advantageous for the speaker combining the expressions of the two languages since one with a mixed language always relates what he would like to say in the language he can express his thoughts more properly. In fact, this is such a code-switching that the recipient may perceive as a single code on the basis of simultaneity of text and picture.

The study highlights reading alternatives that concrete poetry offers us as well as the travel it takes us on. By analysing the mode of interpretation, we can observe how visual poems overbalance the conventional linearity of writing, how figurativity becomes equivalent to the text in the course of creating meaning, while reading is guided by the sight of picture, which confirms the sight as well. Thus, language and picture are practically trapped by the calligram. Text (concrete poetry) understanding is described as integrative by the paper, coming into existence as a result of the constant correction and supplement of situational and ephemeral understandings. It considers the hermeneutical circle/spiral of understanding as a travel, which is always unique and not to be repeated.
\end{abstract}

Keywords: multimediality, concrete poetry, code-switching, reception, understanding 


\section{Introduction}

Nowadays, the abundance of multimedia texts surrounds us. Maybe, because of this, teaching the comprehensive reading of such texts gets increasingly into the forefront of methodological researches. Multimedia text is the combination of several systems of symbols: besides the lingual one or together with it, the musical, pictorial systems of symbol that reach us through the visual/or acoustic communication channel and the extra-linguistic devices are equal or determined in this heterogeneous sign combination such as: concrete poetry, sheet music; in scientific texts: figures, graphs, tables, photos, illustrations with a drawing, etc. (Szikszainé Nagy 2004: 129).

Intermediality, "medial transgression", or "culturally agitating hybridity" is a complex phenomenon resonating and flashing over ages and cultures. We can find it not only in high cultures but in our everyday lives, at all times and in all places (Szúts-Yoo 2014: 13). We can call the group of multimedia texts peculiar of common origin and homogeneity, authentic multimedia texts. These are, for example, the comics, concrete poetry, and the so-called works of concrete poetry, in which the picture and the text are inseparable. Simultaneously, there are texts as well, in which the media come into being with the text, or they may accompany each other, but their contact is not necessarily homogeneity. For example, in folk ballads, although the melody and the text came simultaneously into existence, nowadays, these folklore works are independent texts without melody (Szikszainé Nagy 2004: 131).

\section{Concrete poetry and its interpretation}

The question of aesthetic value comes up, namely: is the text over-subordinated to the form in concrete poetry? Iván Fónagy has the opinion that in most part of these poems the picture substitutes the poetic message. Pál Nagy and Tibor Papp consider concrete poetry as a linguistic and pictorial coded aesthetic message, a poetic intention evolving from the mixture of the verb and the picture (G. Papp 2001: 2).

Concrete poetry broke with the writing tradition that linearizes the words, sentences, and rows. By adjusting to the so-called pictorial form, concrete poetry places the text into the contours of an object. By reducing the meaning, visual poetry aspires after making the written form of the text more expressing.

Concrete poetry is the mixture of text and illustration [...], in which the content is related to the whole picture. The poetic experience and emotional atmosphere manifest themselves in the arrangement of the rows, their type size and graphic. With its visual excess, the concrete 
poetry: brings additional meaning into the poem by its summarization of meaning deriving from the intertwining of verbality and iconity. As a result of this, the picture is in direct or symbolic relationship with the meaning of the text. (Szikszainé Nagy 2004: 134, transl. by Katalin Süge)

If we focus on the story of concrete poetry, we may take a close look at a real riot of colours. This variegation of concrete poetry gives us a literary and, at the same time, fine art experience as a present.

The tradition of visible language is obviously very old and derives from the essence of writing. We may primarily think of cultures such as the Chinese or the Egyptian one but even of the handwritten and painted books of the Middle Ages that likewise indicate relationship with the hypertext, as Proust's novel. At the time of Mannerism and Baroque, the acrostic was handled in different ways, and poems were written in the shape of various flowers, crosses, chalices, body parts, stars, and geometric formations. The message was often formulated in a way that certain letters of the text were emphasized with different types. The picture puzzle-like poem enjoyed particular popularity (Vass 2006: 46).

Apparently, positivism and the realistic novel writing in the historical sense are the reasons why the people in the second half of the $19^{\text {th }}$ century distanced themselves from concrete poetry. In this period, certain scholars of the narrative treated language as a device, namely they assumed its transparency and strove for the reader not to feel its resistance. The reaction began at the end of the $19^{\text {th }}$ century. Mallarmé and Henry James, who - regardless of each other - were against illustrations being made to their works, induced their readers to slow reading by complicating the language (Szegedy-Maszák 2010: 3).

In the $20^{\text {th }}$ century, G. Apollinaire tried to break with the existing traditions; his unconventional endeavours led him to disregard the musicality of the poem. As the creator of concrete poetry, he employs in the first instance the graphic arrangement of the poems for the communication of aesthetic information, although some attempts (see Mallarmé) have already happened before. The period passed since the formation of concrete poetry proves that new opportunities opened in front of the formal development of the poetry, and as a result of this literature implying fine art peculiarities may increase in the future. Visual poetry and respectively the figurative information transfer gains more and more ground because the opportunities of creation of modern rhythms increasingly diminish; nevertheless, the old and tested rhythmical lines gradually become exhausted, automatic, and so they hardly provide any aesthetic experience for the reader; they do not make a deep impression (Zsilka 1969: 1202). The lovers of rhyme, rhythm, and musicality may possibly argue about it, but we have to acknowledge that Apollinaire's form-breaking, unconventional writing opens new ways, new space for literature and poetry. 
The use of typographical devices develops poetry in the direction of fine arts; at the same time, it slightly relieves from the direct effect of music or musicality. This means an innovation since it is an unusual, modern phenomenon. However, the innovation is essential for the development of art and its effective strength (Zsilka 1969: 1203).

As regards form and ideology, the picture is a burdened zone, the escape opportunity of the language, its route, its exit towards the inexpressible or to the one that cannot be represented, as Katalin Sándor outlines rhapsodically. Picture and word: each other's savage and each other's desire, their convergent and divergent motion shed light on the culture, on the function of the cultural recollection (Sándor 2006: 26). In one of Goethe's poems, the word appears in the unbalanced picture of the soul, similarly to how Plato's cave simile sets up the idea. "The word is the shade of the soul, the centre of cognition where things are present with their oral/lingual indexical existence, whereas they appear in incomplete 'pictures', but merely 'silhouettes' - this in any case emphasizes the partial accessibility of things, complains about the cognition exposed to linguistic grasping” (Sz. Molnár 2004: 65, transl. by Katalin Süge). These are the words of faith shattered in the expressive strength of the language, whereby we may argue similarly.

József Balázs Imre looks on concrete poetry from the aspect of the aesthetic of reception and considers it with code-switching. He thinks that for a recipient (of concrete poetry) knowing both languages is more beneficial that the speaker combines the expressions of the two languages since a person using codeswitching always relates what he would like to say in the language he can express himself better. Namely, the recipient obtains the information more expressively, more nuanced than as if it were told only in one of the languages.

Code-switching of concrete poetry certainly differs from the linguistic one in several aspects. With regard to the verbal code, it may be with a full value or, in its case, it does not really incur the risk of coming across the recipient knowing one of the codes only. In fact, this is such a code-switching that the recipient may perceive it as a single code, based on the already mentioned simultaneity (Balázs 1997).

The visual poetry or the various formations of concrete poetry are wellseparable into eras: typical formations of the Baroque Age are figural (picture) poems as, for example, rose poems and quizzes, such as the kubus; the typical formations of historical avant-garde are calligrams and typographical poems; the typical formations of neo-avant-garde tendencies are the concrete, lettrist, and discovered poems etc. (Sz. Molnár 2001: 26).

By a concrete example, in László Nagy's oeuvre, five examples of concrete poetry can be separated. These are the following: calligrams, concrete poetry (compositions edited syntagmatically and morphematically), typestyle, or phonetically edited composition, application and graphics (Vass 2006: 52-53). 
Based on the definition of János S. Petőfi, the subtypes of concrete poetry can be separated as follows: a) are the dominant elements of the visual device verbal linguistic elements (or not)?; b) on which text level(s) can be the dominant verbal elements of the visual device interpreted?; c) the verbal device can be interpreted in itself and the visual component as (its) form model; d) what kind of relations can be detected between the dominant elements of the verbal component and the graphical one; and, finally, e) in what way can the complex communication be classified, more like verbal or rather visual lingual text, namely graphics (Benkes-Petőfi S. 2006: 55).

With the so-called visible language (italic or capitalized writing emphasizing a symbol, punctuation differing from the usual one: the so-called row typography /a term defining the method used by poets to visually emphasize content/), the poets call the reader's attention to additional meaning. Although these are signs appealing to the eye, at the time of scoring, they can be perceived with sound modulations (Szikszainé Nagy 2004: 132). While concrete poetry deals with the language as a substance, the visual one tries to use the contexts as a substance, and since it produces further contexts from context fractions it makes the readers more responsive to a new mentality. Given that, concrete poetry amplifies lingual awareness, visual attempts at improving the consciousness of lingual contexts, and expertise in the lingual external world (Balázs 1997).

The following questions turn up: how is it possible to interpret the meaning of concrete poetry? How can the complex process of understanding become achievable and how is it different from traditional poem interpretation?

Multimedia texts are multiple coded; decoding of simultaneously various codes is required to their reception, respectively the knowledge of similarity, functional relationship existing between the signs of different sign systems, or the interference of the media (Szikszainé Nagy 2004: 138).

What territory is the "buffer zone" of texts and pictures? How do words and pictures meet in the aesthetic experience? They "entertain" each other, while they are perceptible as each other's strangers, unreleased, and, at the same time, with unaffectedness gathered from some atavistic depths. The media do not face each other and cannot be categorically separated either, but they are in contiguous "visit". The medium of picture and language is saturated with each other, it is impure. Verbal and visual parties are not "litigating” parties; opposition limits both of their significance.

The relation of word and picture is multimediality; the intermediality is itemized as substituting, exchange, participation, constraint of media to each other or as an inequality forming configuration, always calling into action some kind of view of betweenness that is not only interesting to what it figures the captions but what kind of readers' positions, reading alternatives it promises (Sándor 2006: 25). 
By recognizing the role of the text's carrier (its physical carrier) meaning formation, Gábor Tolcsvai Nagy conceptualizes concrete poetry in comparison with the linearity of the writing with a more complex character. In his definition, concrete poetry does not merely function on a more complex level of the text's carrier but overbalances the conventional linearity of the writing, our concepts related to (clear) textuality and (clear) visuality, the practice of reading (Tolcsvai Nagy 2001: 112).

Fast reading is interfered with placing the letter in a pictorial figure. Beyond the knowledge of the linguistic peculiarities, taking into consideration the visual aspect, a certain fine art attitude is also essential to the interpretation of concrete poetry. Creation with a visual type implies a different method of reception instead of the traditional one "since not the succession of text sentences is determinative in the meaning assignment but the formal arrangement, beside the sight, text picture connotes the poetical” (Szikszainé Nagy 2004: 138-139, transl. by Katalin Süge).

Since multimedial texts have composite sign organization, diverse coding is indicated to their creation and diverse decoding to their reception. In concrete poetry, breaking the traditional form and renewing it, by text, becoming equivalent to figurativity, will be the basis of attribution of meaning. Instead of the text's (traditionally, linearly) progressive interpretation, creativity relying on recipient fantasy is needed for unravelling visual poetry (its pictorial rebus) (Ibid.).

By analysing expressive devices, Roland Barthes explains that in semiotics two substances may respond to the same form. After all, this kind of distinction is not new-fangled in poetry. As an information recipient, the reader always might enjoy poetry in two ways: either by reading or by listening to a recitation. However, at the time of reception, the experienced reader associates the visual concept with the auditive one and frequently also "transforms" the visual concept into an auditive one. School education is dominantly the tutor for this; namely, it is not a coincidence that our perception is mostly sophisticated to such reception. The use of graphic composition in poetry means breaking with the tradition; still, the reader has to receive the aesthetic information also through the visual channel if he would like to get such information (Zsilka 1969: 1204).

In the calligram, picture and language are in a relationship subordinated to each other, the sight of the picture guides reading, and in the meanwhile reading of the text confirms the sight, just like in the case of the baroque figural poems; as if the pictorial and linguistic part of the emblem poems had slid into each other. In Foucault's interpretation, the calligram thus practically traps language and picture as well (Sz. Molnár 2002: 49).

Áron Kibédi Varga places some characteristic combinations of the word and picture relations in quite a rigid matrix. In this system, concrete poetry can be included in the category that is characterized by simultaneity and uniformity of word and picture, their synthetic nature. Thus, for Kibédi Varga, the principle of simultaneity becomes important. "In case of an emblem or an illustration, we 
may turn with full right from the picture to the text and inversely, or we modify alternately and regularly the manner of perception of a verbal-visual object [...]" (Kibédi Varga 1997: 306, transl. by Katalin Süge).

Wolfgang Iser describes the understanding of the text as an integrative understanding created as a result of constant correction and amplification of situated and instantaneous understandings (namely, it evolves the diversity of applying to the text, which is always with perspective nature because the whole text cannot be realized in a flash). In the case of concrete poetry, we may follow this process in its every detail. As at the time of reading concrete poetry from partial understanding the perception of the whole gradually develops, the same is realized at the time of the reception of all texts; however, in case of concrete poetry, these partial understandings can be much more segmented because its code is constructed from elements of several media. Namely, we can write the reception process in a more exploitable manner onto the analogy of concrete poetry. However, there even exists such a feature of concrete poetry that practically teaches us to read. Primarily, it provides "instructions" to its own interpretation of text, but we may also perceive this guide as a universal one: it slows down the reading and in turn it gives a picture - something which can be contemplated, emotionally experienced, also from an intellectual aspect with the totality, unity of being true to life - as a present to the reader (Balázs 1997).

The captions form us into better readers since the reading is not only reading but at the same time illegibility, receiving, deflecting and self-loss, pain, resistance, and not least wish for reading and writing. Katalin Sándor demonstrates the complexity of the encounter of the language and picture, its occurring with the help of the following expressions: aesthetic break, shift, stress, interactive game, differing, slip, contradiction, non-integrability, divergence, complementarity, etc. (Sándor 2006: 25). The interactive game of picture and text can be interpreted as a never-ending cycle which overshadows the recipient attitude as well.

The reception of concrete poetry does not merely consist of looking at the picture in the first place and later reading the writing which represents the image.

In the light of the lingual text, quite like in the hermeneutical circle/spiral of understanding, we return to the figure, we reveal its relevant meanings by knowing the former ones; if we can interpret the picture symbolically as well, we return to words again by searching for contact between the symbolic meaning and the whole poem. Because of constant feedbacks, we may find the picture and the linguistic text simultaneous. (Balázs 1997)

At the same time, it is essential that concrete poetry is not merely the illustration of its own verbal meaning. Concrete poetry does not say the same in the language of visuality as verbally. 
The poet of concrete poetry aspires after sight and primarily achieves it with the adaptation of confrontation, coincidence, and contradiction. The device of confrontation is often the contrastivity hidden in colours: comparing black with white or grey with black (or white). In this respect, concrete poetry appearing in the children's literature is not an exception either. However, we can notice more frequently the coincidence between different font types and variants as well as between handwritten and printed typefaces. Examples also occur to opposites like straight-curved, big-small, vertical-horizontal, left-right, and up-down (G. Papp 2001: 138).

Do visual poems have a value in the children's literature? Primarily, the question is not whether they have an aesthetic value but if they have a literary aesthetic value. After all, the aesthetic value of the text defines this dominantly.

Of course, we may ask the question why concrete poetry (calligram) does not occur often in our textbooks. Although concrete poetry is not necessarily short, we cannot speak about its graphical aspect a lot - at least it is not easy. Still, we should be surprised at its delicacy, spending more time on it, and not merely on the text but on its form as well - ask, explain, comment, and reveal why a poem has the shape that it has. The real analysis of concrete poetry is actually not easy. It is not a popular task. It is grateful to flash it, but to go further into it is an ungrateful one.

Tibor G. Papp separates four types of calligrams, and from these three are present in the children's literature as well.

a) Calligram 1 - The linguistic theme is linear and corresponds to the normative syntax; the elaborated picture illustrates the message or repeats it.

Reading concrete poetry happens from left to right. So the degradation of form ("its dissolution") responds to the usual poem-building practice: hat, head, and after each other the two word scoops with increasing dimensions. Most of the rows form a syntactic unit, and it could even have a traditional type. The picture formed by the utilisation of graphic conditions of text (fitting typeface and size to the content) repeats the topic of the poem and intensifies it. (It would be an exaggeration to put a separate illustration in addition to this!). (G. Papp 2001: 131)

b) Calligram 2 - The linguistic theme corresponds to normative syntax, but it is not completely linear; thus its interpretation is more difficult.

c) Calligram 3 - The outlined picture does not follow the requirements of normative syntax; however, it is linear in its details. It indicates a logical process.

d) Calligram 4 - The text does not follow the requirements of normative syntax, and it is not linear, not even in its details. There is not always a logical context between the picture and the linguistic theme employed, namely the text. This solution points beyond the children's circle of understanding (Ibid.). 
At the same time, Tibor Papp provides the following classification of visual poems:

1. stative visual poems (two- and three-dimensional poems) and 2. dynamic visual poems (Vass 2006: 53). From these two big domains (stative and visual) of visual literature, stative works have appeared (have taken root) in children's lyric poetry. Besides this, the typical ones are the visual forms emerging through the iconic-logical ordering principle, meaning that the poet arranges the text horizontally so as to create a recognizable view (G. Papp 2001: 130).

In Hungarian vernacular reading books in Vojvodina, concrete poetry is (unfortunately) slightly present. In case of the lower classes, we may find Antal Verbőczi's poem entitled Hóember (Snowman) in second-grade course books, which - based on Tibor G. Papp's typology - can be included in the first group, meaning that the linguistic theme is linear and corresponds with normative syntax, and the elaborated picture illustrates the message or repeats it. After the illustration of personal experiences - by contributing to the encounter of personal world and text world -, the form of concrete poetry comes into the centre of text processing, into the focus, besides the linguistic elements but not instead of them. We have highlighted some similarities between picture, concrete poetry, and the poem. In the meanwhile, students had to recognize/experience the dynamic function of the picture and the text. (In the same publication, Attila Benkő's poem entitled Sorbanállók a fagylaltosnál (Queuers at the Ice-Cream Man) is made up of words only, which stand under each other as a stair, depicting this way the curling line.)

In higher classes, in the eighth class, we have worked out in detail László Nagy’s concrete poetry entitled Tüz (Fire), which, based on Tibor G. Papp's typology, can be similarly included in the first group. We are looking for an answer as to what the unusual form of the poem resembles to; namely, we are trying to find its equivalent part of reality. We investigate whether the poem picture strengthens the meaning and, if so, by what means. We draw the reader's attention to the kind of metaphors and ideas the song generates with hymnal intonation, divided into three parts by accosting us. Christian Morgenstern's poem entitled The Night Song of the Fish serves as illustration, functioning as a complex of signs; the recipient has to find out its meaning. The poem can be rather interpreted as a picture. Of course, it means the same in all languages, it does not need to be translated. Moreover, we have presented to the students Guillame Apollinaire's poem entitled The Stabbed Dove and the Fountain. We emphasized that in this variety of concrete poetry the text is legible and carries a meaning as well. However, the picture and the meaning are connected with each other so much so that it is impossible to quote a passage from it.

In the meantime, our aim would be the acquisition of a different view, the acceptance of mediality, its adequate interpretation. Unfortunately, for the 
achievement of this aim, an insufficient number of concrete poetry works is included in our textbooks, which does not make this possible. As a way of illustration, we may present more from it, showing the dynamic coexistence of picture and text as they "host" each other.

\section{Conclusions}

The phenomenon of reader/writer function has a pragmatic aspect. In traditional literature, the writer (which is only "vaporized" in theory) is a real person, who can fail or become well recognized (Szúts-Yoo 2016: 50).

Concrete poetry demonstrates and specifies, illustrates and reports, reproduces and articulates, imitates and indicates, and beholds and reads. It sets an unavoidable trap. By using the extensity of the writing as a trick, it leaves the visible form of the mark on words as well: with the help of signs carefully distributed on paper, the borderlines formed by them, and their distances in the sheet's void space, they draw forth the subject they talk about (Balázs 1997).

Based on the diverse approach of concrete poetry, I am of the opinion that visual literature, visual poetry raises the question of "how to read" on purpose. A peculiarly released reading characterizes our poem comprehension. Poem reading is the series of unique shifts, constant restructuring of understanding.

Visual poetry is equally less and more than the absolutely verbal poetry: less inasmuch as it fixes the inner sight, directs it towards the orbits of the exterior sight, and, as opposed to the sight, it may make the text secondary; more inasmuch as lingual elements serve as visual elements as well, and this fact in itself provides additional meaning to the work - its new layers may be revealed through further thinking.

In my opinion, textbook writers, teachers should on no account exclude concrete poetry, visual poetry from literary education. They should keep in view the education of Generation Z to become a (comprehending) reader; in any case, they should take this unique opportunity, the incredible effect of picture and concrete poetry. This must become part of the target system of literary education.

\section{References}

Balázs, I. J. 1997. Kétnyelvúség vagy kevertnyelvúség? Szempontok a képvers esztétikájának kidolgozásához [Bilingualism or code-switching? The aspects of outlining the aesthetics of concrete poetry]. Korunk (online) 12. http://korunk. org/?q=node/6209. (Retrieved on: 10 December 2014). 
Benkes, Zs.-Petőfi, S. J. 2006. A vízjel nem tünik el könnyen. Versek megformáltságának megközelítése kreatív gyakorlatokkal [The watermark does not disappear with ease. The approach of forming poems with creative practices]. Budapest: Tinta Könyvkiadó.

Papp K., G. 2001. Képvers a gyermekköltészetben [Concrete poetry in children’s poetry]. Könyv és Nevelés 2001/1: 129-139.

Kibédi Varga, Á. 1997. A szó-és-kép viszonyok leírásának ismérvei [Criteria of the description of word-and-picture relations]. In: Bacsó, Béla (ed.), Kép - fenomén - valóság. Pécs: Kijárat. 300-320.

Sándor, K. 2006. Közelítések a médiumköziség kérdéseihez I. [Approaches to intermediality I.]. Iskolakultúra 1: 17-36.

Szegedy-Maszák, M. 2010. KÉP/VERS, vizuális és konkrét költészet [Visual poetry - concrete texts]. Balkon 4: 2-4.

Szikszainé Nagy, I. 2004. Leíró magyar szövegtan [Descriptive Hungarian textology]. Budapest: Osiris Kiadó.

Sz. Molnár, Sz. 2001. Vizuális költészet vagy képvers? A képvers-értés szempontjai a magyar irodalomtörténet-írásban [Visual or concrete poetry? The aspects of understanding concrete poetry in Hungarian literary history writing]. Iskolakultúra 10: 26-38.

2002. A képvers-értés története: a történeti avantgárd [The history of understanding concrete poetry: the historical avant-garde]. Iskolakultúra 11: 46-60.

2004. A képvers-értés története: a neoavantgárd [The history of understanding concrete poetry: the historical neoavantgarde]. Iskolakultúra 4: 61-70.

Szűts, Zoltán-Yoo, Jinil. 2014. Interactivity and reception. The question of hypermedial, geo-spatial and augmented literature. World Literature Studies 4: 13-26.

2016. Reading from and writing on screens: a theory of two literatures. World Literature Stadies 3: 40-56.

Tolcsvai Nagy, Gábor. 2001. A magyar nyelv szövegtana [Textology of the Hungarian language]. Budapest: Nemzeti Tankönyvkiadó.

Vass, László. 2006. A vizuális költemények csoportosítása Nagy László alkotásai alapján. [Classification of the visual poems based on László Nagy’s writings]. Iskolakultúra 1: 46-55.

Zsilka, Tibor. 1969. A képvers és az olvasó. Illyés Gyula „Újévi ablak” c. versének interpretációja [Concrete poetry and the reader. Interpretation of Gyula Illyés's poem entitled “Újévi ablak”]. Híd 11-12: 1201-1208. 